\title{
Managing cyanotoxin risks at the drinking-water offtake
}

\author{
Justin Brookes, Mike Burch, \\ Gesche Grützmacher, and Sondra Klitzke
}

\section{CONTENTS}

Introduction

9.1 Optimising the location and depth for the offtake 564

9.1.1 Vertical variability of cyanobacterial occurrence 564

9.1.1.1 Balancing cyanobacterial risk against other contaminants

9.1.1.2 Releasing poor-quality water downstream

9.1.2 Horizontal variability of cyanobacterial occurrence

9.1.3 Data collection for optimising offtake sites

9.1.4 Operational monitoring of control measures in raw water abstraction

9.1.5 Validation of control measures for raw water offtake

9.2 Sediment passage: managed aquifer recharge via soil aquifer treatment or pond infiltration, slow (sand) filtration and bank filtration

9.2.1 Background information to assess the subsurface conditions relevant for performance in retaining cells and dissolved cyanotoxins

9.2.2 Degradation of microcystin during bank filtration

9.2.3 Degradation of cylindrospermopsin during bank filtration

9.2.4 Degradation of other cyanotoxins during bank filtration

9.2.5 Planning, design and construction of sediment passage for cyanotoxin control

9.2.6 Critical aspects of operation, maintenance and monitoring

9.2.7 Assessing the risk of cyanotoxin breakthrough where drinking-water is abstracted by magaged aquifer recharge and/or slow sand filtration 
9.2.8 Operational monitoring of sediment passage as control measure against cyanotoxins

9.2.9 Validation of control measures in sediment passage 586 References

\section{INTRODUCTION}

The characteristics of cyanobacteria to form surface scums or subsurface accumulation in deeper layers (see Chapter 4) mean there can be patchy and variable vertical and horizontal distribution of cells. This is important to consider for abstracting drinking-water from surface waterbodies. The intake of cyanobacterial biomass and cyanotoxins in the raw water can potentially be greatly reduced - sometimes by orders of magnitude - if site and depth of drinking-water abstraction are chosen to avoid these accumulations. The water offtake is one of the few control points available to managers to improve the quality of abstracted water and thereby ensure product water quality following treatment. Where control of abstraction is possible, the challenge to drinking-water treatment from high levels of biomass, DOC, TOC (dissolved and total organic carbon) and cyanotoxins can be managed in order to reduce the reliance and pressure on water treatment options (see Chapter 10).

Where surface water can be filtered through sediment, that is, by abstraction through bank filtration or artificial groundwater recharge, or if slow sand filtration can be installed, if operated with sufficiently low and long filtration rates, this can also be highly effective in removing both cyanobacterial cells (as well as other particles, including pathogens) and dissolved toxins.

\section{I OPTIMISING THE LOCATION AND DEPTH FOR THE OFFTAKE}

\section{I.I Vertical variability of cyanobacterial occurrence}

Spatial and vertical variability in the concentration of contaminants in lakes and reservoirs, as described in section 4.6.4, is common. This applies not only to cyanobacteria but also to pathogens, iron, manganese and other contaminants. Thermal stratification of the waterbody leads to warmer water layered above cooler, denser water. This provides suitable conditions for cyanobacterial growth as the common bloom-forming types are buoyant and can avoid sedimentation losses during the periods of stratification. Under some conditions, the cyanobacteria can accumulate to scums at the surface, and in mesotrophic waterbodies, the maximum concentration can occur as a band in a deeper layer, as discussed in section 4.2.1. 
Many modern reservoir offtake structures (often towers but also some dams) have multiple offtake depths as part of good design. If multiple offtakes are not available, in small systems it may be possible to siphon water from a specific depth using large pipes as a temporary management measure. The depth at which cyanobacterial cell densities are greatest - at the surface or at specific depths - may show diurnal and seasonal patterns, and the range of passive diurnal sinking and rising of cells is due to light- and photosynthetic-driven changes in cell buoyancy (section 4.1.2). While the high variability in surface concentrations can be a relevant risk in all waterbodies, the formation of pronounced layers or maxima at deeper and often variable depths may only be relevant in thermally stratified (see section 4.3.4) mesotrophic reservoirs. The best-known example of this occurs in temperate regions with the formation of distinctive deep metalimnetic maxima of low-light-adapted Planktothrix rubescens. In subtropical and tropical systems, Raphidiopsis (Cylindrospermopsis) raciborskii can also reach high numbers deeper in the epilimnion, but these rarely form surface scums.

Figure 9.1 provides a good example of spatial variability and vertical patterns for buoyant cyanobacteria in a medium-sized reservoir. These

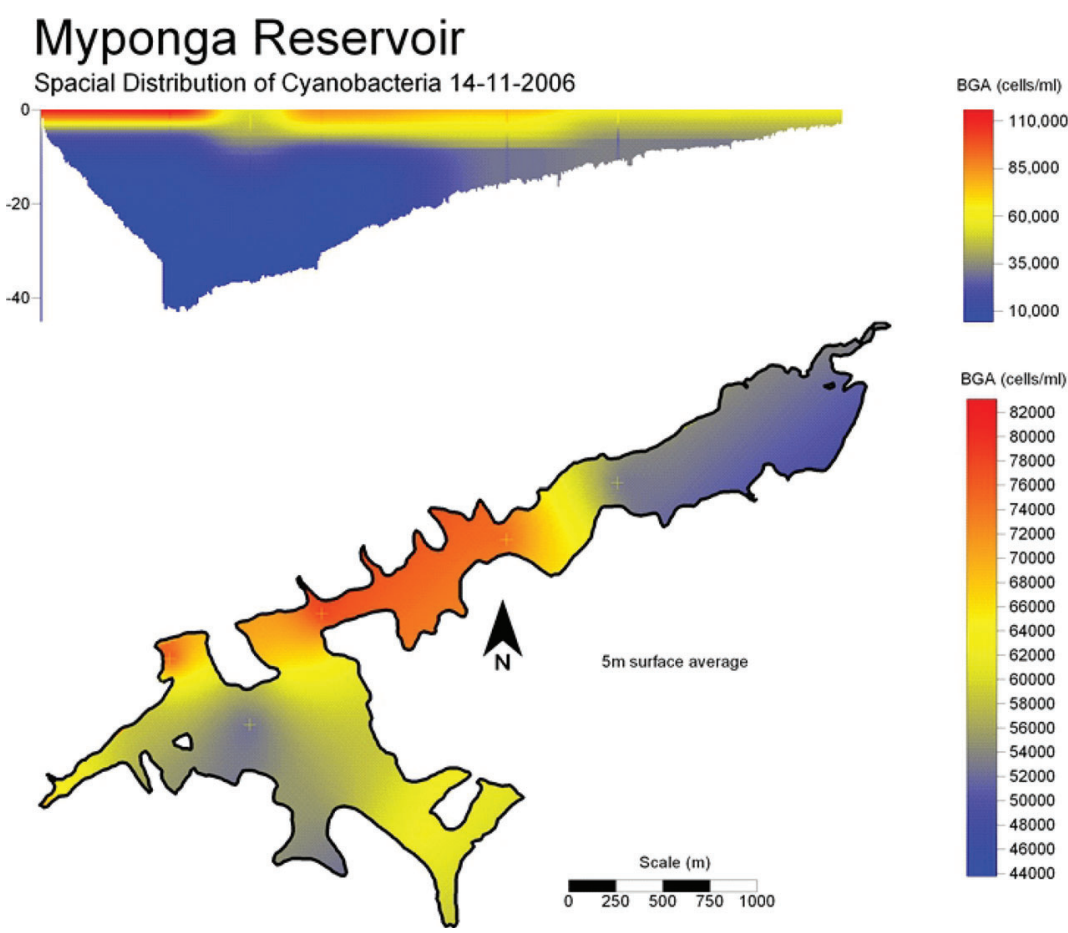

Figure 9.I Vertical profiles and horizontal variability of a population of Dolichospermum circinale in a horizontal transect across a reservoir in South Australia measured by phycocyanin fluorescence, converted to cells per $\mathrm{mL}$. 
cyanobacteria, predominantly Dolichospermum circinale, develop surface and subsurface maxima at several depths at the deepest site (Site 1), while more mixing occurs at shallower locations in the reservoir (Sites 6-8). This accumulation of buoyant cyanobacteria is associated with temperature stability in the growing season and shows how strong surface maxima can develop near the reservoir surface while very low numbers occur in deeper water. This drinking-water reservoir has the option for water offtake at the surface, 5,15 and $25 \mathrm{~m}$ at Site 1 . The operational practice at this reservoir is to draw water from a depth of 25 or $15 \mathrm{~m}$ when cyanobacteria are present, which leads to much lower intake of both cells and potentially toxin and odour metabolites into the water treatment plant. A further case study is given by Fastner et al. (2001) for the Deesbach Reservoir, where at that time surface concentrations ranged up to $570 \mu \mathrm{g} / \mathrm{L}$, while at the offtake depth of $17 \mathrm{~m}$, they were in the range of less than $1 \mu \mathrm{g} / \mathrm{L}$.

In conclusion, it is important for operators to obtain information about the range of vertical movement of local cyanobacterial populations and also to be aware of the potential for the formation of metalimnetic (deep-depth) maxima in order to avoid drawing high cell densities into the raw water intake. This requires multiple depth sampling or probe measurements to determine vertical profiles of cyanobacterial cell density (see Chapters 11 and 12 for methods).

\section{I.I.I Balancing cyanobacterial risk against other contaminants}

Selecting the optimal abstraction depth to minimise the cyanotoxin risk requires awareness of the depth distribution of other water contaminants - that is, pathogens, dissolved organic carbon, iron and manganese. The greatest challenges from cyanobacteria, iron and manganese generally occur during stable, stratified conditions. The greatest challenges from pathogens and dissolved organic carbon occur through transport of these contaminants from the catchment during heavy rain event-driven inflows. For an early detection of a potential for cyanobacterial proliferation, an understanding of the impact of the local weather and hydrological conditions is of great value (see Chapter 4).

River water enters a lake or reservoir as an intrusion and will flow through the reservoir at a depth determined by its density (in turn dependent on temperature and conductivity) relative to the density of the reservoir water (Figure 9.2). If the river inflow is cold and dense relative to the reservoir water, the river water will move into the reservoir as an underflow. The river inflow or "intrusion" may also travel at mid-depths or towards the surface, depending upon temperature and density. It is possible to determine the depth of the riverine intrusion using a simple online tool which considers temperature detailed in section 9.1.4. 


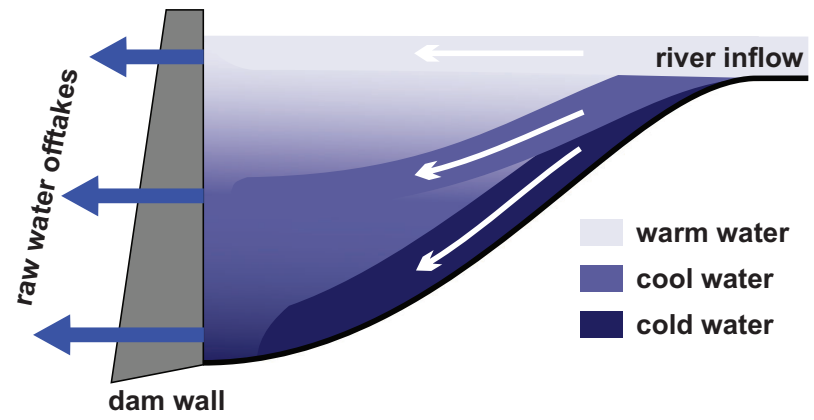

Figure 9.2 Formation of river water intrusions during inflow events. The darker the shading, the colder and denser the water. The depth of formation of the riverine intrusion will correspond to the depth in the reservoir at which water has equivalent density.

\section{I.I.2 Releasing poor-quality water downstream}

The water abstraction depth can also be utilised to release water of poorer quality downstream and optimise the quality of water remaining in the reservoir. Riverine intrusions into a reservoir often have a higher concentration of phosphorus and nitrogen, so releasing this water downstream can result in lower reservoir nutrient concentrations in the reservoir, thus reducing the maximum achievable cyanobacterial biomass. This method is generally only suitable in areas without water shortage, while in arid regions, water harvesting is often maximised, therefore avoiding downstream release. Also, the quality impact of the water released to the downstream river reach may be an issue to clarify with stakeholders and authorities responsible for the river water quality (often, this impact is minor and only relevant for a very short downstream part of the river).

\subsubsection{Horizontal variability of cyanobacterial occurrence}

The horizontal variation in the distribution of cyanobacterial populations can also be considerable. Figure 9.1 shows the horizontal and vertical heterogeneity of cyanobacterial distribution. Observing seasonal patterns of cyanobacterial scum location and/or predicting them from the main wind direction may be useful for planning a drinking-water offtake or the location of a recreational site or beach (see below).

Substantial contamination of raw water can be avoided by locating offtakes away from sheltered bays where scums may accumulate (usually downwind of the prevailing winds during the critical summer growth period). If this is not practical, it may be possible to employ temporary extensions to pipe intake points. 
Where the offtake or recreational site already exists and relocation is not an option, physical barriers may serve to exclude the most pronounced blooms. They prevent surface scums accumulating near the offtake site. Surface booms or curtains, similar to oil-spill containment booms, have been used successfully in Australia, the UK and North America to keep surface scums away from offtake structures. These physical barriers usually extend to a depth of $0.5-1.0 \mathrm{~m}$ and thus do not affect bulk horizontal flow significantly. This technique is a worthwhile practical emergency measure for transient blooms, and its use will depend upon the technical requirements of installation.

\subsubsection{Data collection for optimising offtake sites}

Collecting information as well as building knowledge and understanding of the local ecology and conditions can greatly increase flexibility in responses to blooms. When collecting data to optimise offtake depth, it is important to include relevant hazards or indicators for their occurrence. Vertical profiles of temperature provide a basis for assessing thermal stratification, and profiles of oxygen concentration and redox potential indicate the likelihood of higher iron and manganese concentrations. Data from turbidity profiles may also be useful to indicate the location of a bloom. Many water quality probes that measure temperature, conductivity, dissolved oxygen, etc can also be equipped with a fluorometer, which measures chlorophyll, including the specific or other pigment fluorescence - a useful surrogate for phytoplankton biomass. Fluorometers can specifically differentiate between cyanobacteria and other phytoplankton if they measure phycocyanin fluorescence, an accessory pigment only of the cyanobacteria. While the ratio between cyanobacterial biomass and the fluorescence signal may vary to some extent, fluorescence signals have proven highly useful as a relative measure of the distribution of blooms, both vertically and horizontally. These probes may be installed online at offtakes as part of Alert Level Frameworks (see section 5.1.2) to adjust water treatment responses. The fluorometry signal can be calibrated by comparing phycocyanin fluorescence with the monitored cell counts (section 13.6.1). However, it is important to be aware of the issues and technical limitations of in situ fluorometers for monitoring of cyanobacteria (see, e.g., Zamyadi et al., 2016 or Bertone et al., 2018).

The following checklist outlines information needed to assess cyanotoxin intake from raw water offtake systems. It is neither complete nor designed as a template for direct use, and should be adapted to specific local conditions. Support from lake experts or limnologists with hydrodynamic expertise is highly valuable for this assessment. For measures to minimise the occurrence of cyanobacteria through reducing nutrient loading or waterbody management, see Chapters 7 and 8 . 


\section{CHECKLIST 9.I: COLLECTING INFORMATION ON THE RISK OF INTAKE OF CYANOBACTERIA OR DISSOLVED CYANOTOXINS WITH THE DRINKING-WATER OFFTAKE}

What meteorological, hydromorphological and hydrodynamics characteristics of the waterbody could affect cyanobacterial distribution?

- Compile information on depth, volume, bathymetry and thermal stratification;

- Collect information on the prevailing wind speed and direction;

- Determine the location of raw water offtake.

What information is available on cyanobacterial or cyanotoxin occurrence, and where they tend to accumulate in relation to the drinking-water intake?

- Collate historical information on the occurrence of cyanobacteria and consider initiating a new programme or adapting an ongoing programme to survey cyanobacterial occurrence and to determine differences in their distribution.

- Evaluate the local cyanobacterial species with regard to their buoyancy characteristics and their potential vertical distribution.

What data are available and/or necessary to inform selection of an offtake site?

- Determine the scale of monitoring and expertise necessary and available to effectively manage the offtake.

- Assess whether continuous online monitoring of temperature profiles could be installed to better understand both thermal stratification and flow regime, and whether the information gained is likely to justify the costs.

- Evaluate whether sensors could be installed to effectively monitor the offtake for the indication of cyanobacterial biomass, for example, phycocyanin fluorescence, chlorophyll fluorescence and turbidity.

Are hazardous events likely to cause cyanobacteria to concentrate near the offtake?

- How heavy are cyanobacterial blooms? How long do they persist, and what seasonal patterns do they show? Which toxins do they contain? Are substantial extracellular amounts of toxin likely? 
- Assess whether scum-forming cyanobacteria are likely to accumulate at the surface and to concentrate on leeward shores due to wind action.

- Assess whether storm event inflows will transport high concentrations of cells to the offtake from upstream of the waterbody.

Where blooms occur at the offtake, are cells likely to die and lyse through pumping the water from the offtake site to the waterworks?

What management options are available for the drinking-water offtake?

- For thermally stratifying lakes and reservoirs, is a multilevel offtake available? If so, can it be readily operated based upon current monitoring information? If not, can effective options for monitoring indicators for cyanobacterial biomass be installed?

- For thermally stratifying lakes and reservoirs with heavy cyanobacterial blooms, is artificial mixing an option? That is, can aeration sufficiently suppress their development (e.g., through intermittent operation) or shift cell distribution to reduce concentrations at the intake (see also Chapter 8)?

- For near-surface intakes (particularly from shallow waterbodies), determine whether their sites are optimal in relation to chief areas of bloom accumulation and if not, whether relocation (e.g., through pipe extension) is possible.

- For bloom-affected near-surface intakes which cannot be relocated, consider installing physical barriers as discussed above to reduce bloom intake.

What other water quality hazards should be considered when changing an offtake for cyanobacterial management?

- Check whether avoiding the intake of pathogens is an important target for reservoir offtake management.

- Assess whether intake needs to periodically avoid depth layers which have low dissolved oxygen or with high iron or manganese concentrations.

- Develop a strategy for balancing cyanobacterial hazards against other hazards associated with low dissolved oxygen, iron and manganese, or pathogens in inflows.

What regulatory framework exists for abstracting drinking-water?

- Are there surface water abstraction regulations that need to be considered when planning offtake sites and amounts? 
Document and visualise the information on the abstraction scheme and regime:

- Compile a summary report and consolidate information from your checklist.

- Map the spatial distribution of existing or potential sites for raw water intake.

Outcome of system assessment:

- Estimate the risk of cyanotoxin intake: What maximum levels do you expect to find, and for what time periods?

- Estimate the uncertainty of this assessment: Is the information base sufficient to make management decisions? If not, which information gaps should be closed and with which priority?

\subsubsection{Operational monitoring of control measures in raw water abstraction}

The most effective way to ensure that control measures are operating as intended is to monitor readily observable indicators that show whether structures are intact and processes operating as intended - that is, operational monitoring (Chapter 6). For the measures proposed above to control cyanotoxin concentrations in raw water intakes, operational monitoring will largely address the integrity of structures and whether flexible choice of offtake is operated adequately in relation to bloom occurrence. Surveillance will check the records of this monitoring as well as the adequacy of planning and design.

\subsubsection{Validation of control measures for raw water offtake}

Validation to ensure that the drinking-water offtake is appropriately sited and performing optimally is best achieved by a cyanobacterial monitoring programme during a bloom period (Table 9.1). The validation programme would ideally include several different bloom events, consider how wind direction influences the accumulation of scums and consider different types of cyanobacteria with different properties that may occur (e.g., scum-forming Microcystis versus dispersed filamentous Planktothrix agardhii). Several parameters for cyanobacterial biomass measurement may be used for these investigations, including biovolume, pigment analysis either by in situ measurement of fluorescence by fluoroprobe 
Table 9.I Examples for control measures in drinking-water offtake with options for monitoring their functioning

\begin{tabular}{|c|c|c|}
\hline Process step & $\begin{array}{c}\text { Examples of control measures for intake } \\
\text { of contaminants }\end{array}$ & $\begin{array}{l}\text { Options for monitoring their } \\
\text { functioning }\end{array}$ \\
\hline \multirow[t]{2}{*}{ Planning } & $\begin{array}{l}\text { Appropriate selection of offtake site } \\
\text { and depth in relation to } \\
\text { cyanobacterial and cyanotoxin } \\
\text { accumulation, including the } \\
\text { occurrence of other detrimental or } \\
\text { hazardous contaminants (e.g., iron, } \\
\text { manganese, pathogens) }\end{array}$ & $\begin{array}{l}\text { Review plans/applications } \\
\text { for permits in relation } \\
\text { to information on bloom } \\
\text { accumulation and occurrence } \\
\text { of other contaminants }\end{array}$ \\
\hline & $\begin{array}{l}\text { Downstream release of nutrient-rich } \\
\text { water, artificial mixing or physical } \\
\text { barriers against surface scums }\end{array}$ & $\begin{array}{l}\text { Review plans and applications } \\
\text { for permits }\end{array}$ \\
\hline \multirow[t]{6}{*}{$\begin{array}{l}\text { Design, } \\
\text { construction, } \\
\text { maintenance }\end{array}$} & $\begin{array}{l}\text { Ensure that offtake structures (e.g., } \\
\text { extension pipes, depth-variable } \\
\text { offtakes) are constructed according } \\
\text { to good practice and that they are } \\
\text { withdrawing water at the location } \\
\text { intended }\end{array}$ & $\begin{array}{l}\text { Inspect structures during } \\
\text { construction and at intervals } \\
\text { during operation; monitor } \\
\text { their integrity }\end{array}$ \\
\hline & $\begin{array}{l}\text { If measures such as downstream } \\
\text { release of nutrient-rich water, } \\
\text { artificial mixing or physical barriers } \\
\text { against surface scums are } \\
\text { implemented, ensure proper design, } \\
\text { construction, maintenance }\end{array}$ & $\begin{array}{l}\text { Inspect structures during } \\
\text { construction and at intervals } \\
\text { during operation; inspect } \\
\text { records of maintenance }\end{array}$ \\
\hline & $\begin{array}{l}\text { Adapt variable offtake depth to } \\
\text { stratification of cyanobacterial } \\
\text { accumulation, taking other } \\
\text { contaminants (iron, manganese) into } \\
\text { account }\end{array}$ & $\begin{array}{l}\text { As above, but for deep-layer } \\
\text { offtakes include redox } \\
\text { measurement or oxygen } \\
\text { concentration to detect high } \\
\text { levels of iron/manganese }\end{array}$ \\
\hline & $\begin{array}{l}\text { If artificial destratification is used, } \\
\text { adapt the mixing intensity to stability } \\
\text { of thermal stratification }\end{array}$ & $\begin{array}{l}\text { Monitor temperature profiles } \\
\text { over depth in reservoir or } \\
\text { lake }\end{array}$ \\
\hline & $\begin{array}{l}\text { If artificial mixing is intermittent, adapt } \\
\text { periodicity to phytoplankton } \\
\text { development }\end{array}$ & $\begin{array}{l}\text { Monitor phytoplankton } \\
\text { development, for example, } \\
\text { by fluorescence (differentiating } \\
\text { between cyanobacteria and } \\
\text { algae); verify qualitatively by } \\
\text { microscopy }\end{array}$ \\
\hline & $\begin{array}{l}\text { If physical barriers to deflect blooms } \\
\text { are in place, monitor their integrity } \\
\text { and proper positioning }\end{array}$ & $\begin{array}{l}\text { Visual inspection, possibly } \\
\text { supported by on-site } \\
\text { probing of fluorescence or } \\
\text { turbidity }\end{array}$ \\
\hline
\end{tabular}


(preferably distinguishing between chlorophyll- $a$ and phycocyanin specific for cyanobacteria) or chlorophyll extraction and photometric determination (in conjunction with qualitative microscopy to determine the proportion of chlorophyll that is likely to originate from cyanobacteria). Other parameters indicating the amount of cyanobacterial biomass may be used as well, including cell counts, molecular information, remote sensing data or turbidity measurements (as with chlorophyll- $a$, in conjunction with qualitative microscopy to check whether a major fraction of the turbidity is likely to originate from cyanobacteria). While these are less precise, they can be very suitable surrogate monitoring parameters particularly if locally "calibrated" against periodic toxin analyses as described in Chapter 5.

Validation would also include other contaminants to determine differences in spatial distribution compared to that of the cyanobacteria, for example, iron and manganese or pathogens potentially accumulating in the hypolimnion. This is to ensure that optimising for cyanotoxin control does conflict with optimising for the control of other contaminants. Validation should be repeated from time to time, particularly if bloom patterns show conspicuous changes or if the hydrodynamics of the waterbody have changed.

\subsection{SEDIMENT PASSAGE: MANAGED AQUIFER RECHARGE VIA SOIL AQUIFER TREATMENT OR POND INFILTRATION, SLOW (SAND) FILTRATION AND BANK FILTRATION}

In many settings, managed aquifer recharge (MAR; Tufenkji et al., 2002; Maeng et al., 2010; Romero et al., 2014) or slow sand filtration (Ellis \& Wood, 1985; Haig et al., 2011) has proven to be highly effective and low-cost options for the removal of cyanobacteria and dissolved cyanotoxins (Grützmacher et al., 2002). A prerequisite for MAR is the suitability of the given sediment (which is not always given, e.g., in rocky mountainous or karstic regions) or the availability of space for constructing and operating slow sand filters (which may be a constraint where large volumes of water need to be treated). For many scenarios of cyanotoxin occurrence and conditions for MAR or slow sand filtration, substantial toxin removal is very likely. It is thus a very valuable option 
worth considering when assessing a given drinking-water supply at risk of cyanotoxin contamination.

Managed aquifer recharge utilizes subsurface passage through porous media (mostly gravel or sandy material) to achieve purification of surface water for drinking water production. Types of MAR are e.g., bank filtration (Figure 9.3), pond infiltration or aquifer recharge via trenches or injection wells (an overview of techniques applied in Europe is given in Sprenger et al. (2017). Slow sand filtration (Figure 9.4) uses the same principle, though on a smaller scale, i.e., through a less thick layer of porous medium. All these methods are applied in a wide variety of cases with different results and can therefore be seen as abstraction methods, pre-treatment or treatment steps.

Managed aquifer recharge comprises both systems saturated with water (i.e., riverbank filtration, groundwater and (slow) sand filtration) and unsaturated systems such as soils, in which not all pores are filled with water, leading to different transport dynamics, especially to higher temporal variability. Therefore, some of the processes eliminating cyanotoxins differ between both, and hence, results from saturated systems cannot always be transferred to unsaturated systems. The following sections give an overview on the removal of different cyanotoxins in various managed aquifer recharge systems, as well as information on different aspects of managing these systems.

\subsection{Background information to assess the subsurface conditions relevant for performance in retaining cells and dissolved cyanotoxins}

Soil aquifer treatment is one type of managed aquifer recharge, in which irrigation water that may contain toxins is applied onto soil. The soil is meant to act as a filter to retain toxins and to prevent them from further transport to groundwater.

Bank filtration is characterised by drinking-water wells in the vicinity of a lake or river that are fed mainly by water infiltrating from the surface water supply (Figure 9.3). For other types of MAR, surface water is first conveyed into infiltration ponds, trenches or wells from which it infiltrates into the subsurface aquifer and is reclaimed in nearby wells. Due to different hydrogeological settings, residence times may vary between a few days to several months. The decisive parameters for the residence time are the hydraulic conductivity of the aquifer (governed by the grain size distribution as well as the existence of a clogging layer) and the distance between point of infiltration and well. Usually, infiltrated surface water blends in the well with ambient groundwater, diluting possible contaminants originating from the surface water (and vice versa; however, groundwater contaminants may also be diluted by uncontaminated surface water).

An important mechanism of sediment passage is the reduction of peak contaminant concentrations by dispersion (i.e., mixing of water with 
different residence times due to varying flow paths). This may help avoid hazardous concentrations, though it does not serve to reduce the total load of the contaminant (this is also true for the decrease in concentration by mixing with groundwater). The main purification processes during infiltration and subsurface passage are straining of particles as well as adsorption onto aquifer material and biological or chemical degradation of dissolved substances.

For predominantly cell-bound cyanotoxins, the main elimination process is the straining of cells on the sediment surface. Phytoplankton removal through sand filtration is very efficient and may eliminate up to $97 \%$ (Pereira et al., 2012). Efficacy may be limited if the grain size distribution of the

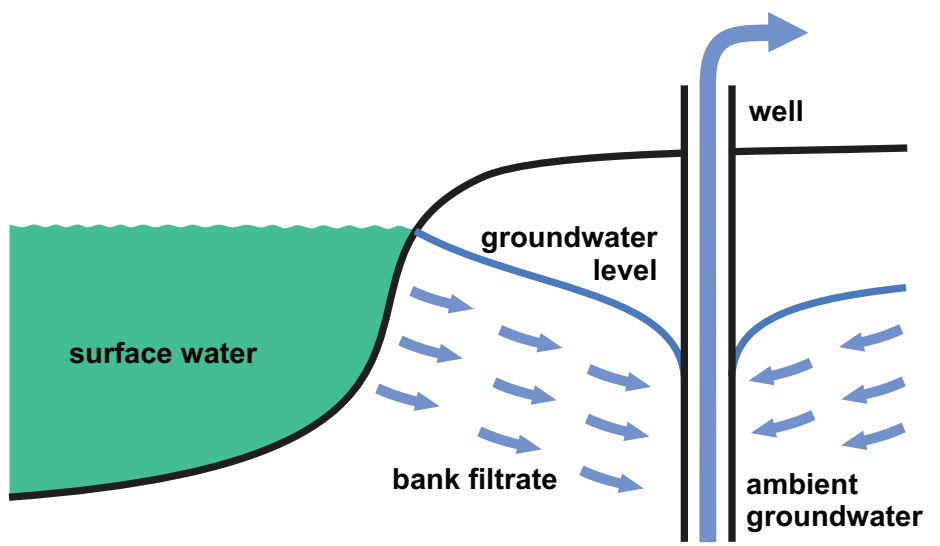

Figure 9.3 Bank filtration scheme. (Adapted by permission from Springer Nature, Hydrogeology Journal, Future management of aquifer recharge. Dillon P. Copyright Springer Nature 2005. www.springernature.com/gp.)

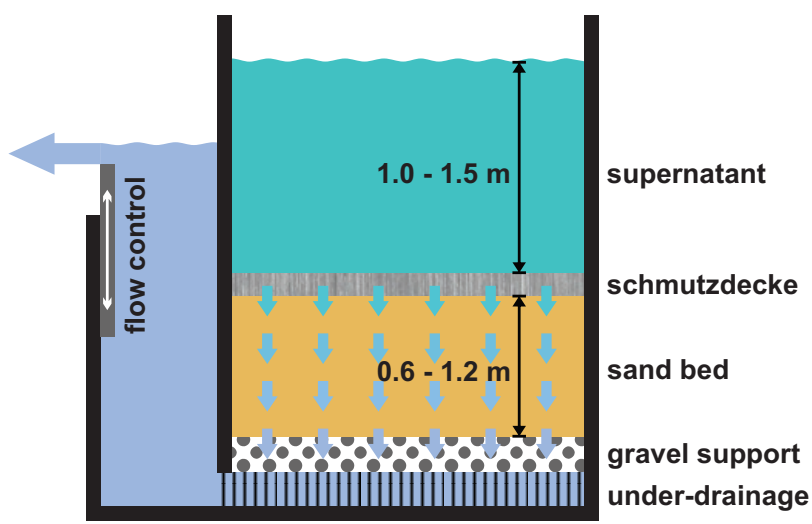

Figure 9.4 Slow sand filtration scheme. Raw water passes the sand filter through gravity. The hydrostatic pressure is controlled by a flow control. 
sediment is coarse (e.g., gravel) and if there is no clogging layer (the clogging layer is defined as the uppermost part of a sediment or filter in which hydraulic conductivity is reduced due to the accumulation of organic and inorganic debris as well as biofilms resulting from high biological activity). An additional parameter that may limit cell removal is the morphotype of the cyanobacterial species (see review by Romero et al., 2014): removal of filamentous cyanobacteria may be more effective than that of single cells or small colonies. Where cell removal is effective, cyanotoxin transport is limited to the migration of dissolved (extracellular) toxins through the subsurface.

As cell lysis may release high amounts of toxin (see Chapter 4), the accumulation of cells on the sediment surface or filter is best avoided. Therefore, in controlled MAR systems or slow sand filtration, it may be necessary to reduce flow rates of feeding water, and to remove upper layers of the filter sand more frequently during periods of cyanobacterial blooms.

Depending on the sediment characteristics (clay/silt content, fraction of organic matter) and the type of cyanotoxins, reversible sorption as well as biological degradation may reduce concentrations of extracellular toxin during subsurface passage. Reversible sorption will only lead to retardation and not to the removal of dissolved toxins, but with the benefit of expanding the residence time during which the cyanotoxins are available for biodegradation. Biodegradation is the only sustainable process leading to a complete cyanotoxin removal. The efficacy of biodegradation depends on redox conditions, temperature and previous cyanotoxin contact of the sediment, which enhances the establishment of effectively degrading microbial consortia.

The residence time in the sediment necessary to achieve the removal target depends on these conditions as well as on the sediment structure and material: a sufficiently large fraction of fine particles is necessary to provide surface area not only for sorption, but also for the establishment of biofilms that harbour the toxin-degrading microorganisms. A fraction of $>1 \%$ fines (i.e., particle size $<63 \mu \mathrm{m}$, consisting of clay and silt) has proven effective, though this might significantly reduce permeability. Sediment structure also determines residence time: if it consists of coarse gravel, throughflow will be rapid.

However, in soil aquifer treatment, toxins merely adsorbed to soils, without being subject to biodegradation, may be desorbed and subsequently leached to groundwater. Studies on the leaching of cyanobacterial toxins from soils to groundwater are scarce (Machado et al., 2017). Batch studies show that MC-LR sorbs well to clay and organic matter (Miller et al., 2001) and several soil bacteria were reported to break down MC-LR (Machado et al., 2017). However, Corbel et al. (2014) showed only a small amount of applied MC-LR to silty sand to be degraded, whereas the largest fraction of the applied toxin remained sorbed in extractible soil fractions. This toxin thus has the potential to be remobilized, for instance during precipitation or irrigation events. The authors assess this toxin's leaching potential from soil to groundwater to be high. So far, there are no studies which investigated the leaching potential of CYN in soils, but due to its low sorption 
potential (Klitzke et al., 2011b) its mobility, i.e. leaching potential, is likely to be high.

The leaching potential of cyanobacterial toxins strongly depends on site conditions such as soil texture, irrigation frequency with polluted water and toxin concentrations in the water as well as time elapsed after toxin application. Due to the lack of data, general management recommencations cannot be derived, and site-specific validation is necessary. Because of the potential risk of leaching, where water with high toxin concentrations is applied in soil aquifer treatment, validation of removal efficacy is particularly important.

Knowledge on sediment passage elimination varies between types of cyanotoxins, with a large share of publications reporting on microcystin and relatively few on cylindrospermopsin, saxitoxin and anatoxin.

\subsubsection{Degradation of microcystin during bank filtration}

Biodegradation as opposed to sorption was found to be the dominating process for microcystin elimination in sandy porous material (Grützmacher et al., 2010). While sorption on sandy aquifer material was very low (Grützmacher et al., 2010), clay (Wu et al., 2011) and silt were found to contribute to microcystin adsorption (Miller et al., 2005). Organic carbon did not enhance microcystin adsorption. Miller et al. (2005) and Wu et al. (2011) even observed a decrease in microcystin sorption at low organic carbon contents (i.e., $<8 \%$ ). The authors explain this decrease by sorption competition between dissolved organic substances and microcystin.

Grützmacher et al. (2002) demonstrated an efficient removal of microcystins by slow sand filtration, simulating the first few decimetres of subsurface passage also for sandy bank filtration and aquifer recharge sites. Under optimal conditions (aerobic, moderate to high temperatures and previous microcystin contact), degradation is rapid, with rates of around $1 / \mathrm{d}$ (assuming exponential first-order decay). The residence time in the sediment needed for sufficient toxin removal $(<1 \mu \mathrm{g} / \mathrm{L})$ under optimal conditions even for very high microcystin concentrations amounts to 10 days. At less-than-optimal conditions, microcystins will also be degraded, though at a slower rate (Grützmacher et al., 2007).

Each of the critical conditions described in the following increases the probability that the minimum residence times necessary for sufficient toxin removal will be achieved or exceeded.

Anaerobiclanoxic degradation of microcystins: It may be much slower than degradation under aerobic conditions. Lag phases may occur but rarely last more than 1-2 days (Grützmacher et al., 2010). Redox conditions in the subsurface may be monitored by regular sampling of observation wells in the flow path, analysis of redox-sensitive parameters (e.g., iron and ammonium) and measurement of oxygen content. 
Lack of previous contact of the system with microcystins: Previous microcystin contact will be given for most settings as water reservoirs and rivers with toxic cyanobacterial mass occurrences tend to show these regularly. Even for surface waters without a history of cyanobacterial blooms, the time usually needed for a mass occurrence to develop (i.e., a few weeks) is likely to be sufficient for adaptation of bacteria in the subsurface. This may, however, be a crucial point for managed aquifer recharge (MAR) sites and slow filtration if sand/sediment has been exchanged just before or during a massive cyanobacterial bloom. Checking records for sediment exchange may therefore be important when increasing amounts of cyanobacteria or blooms are observed.

Low temperature: Temperature generally determines microbial degradation rates. For microcystins, this is also generally true, but there is some experimental evidence that microbial communities may adapt to low temperatures and yield high degradation rates even at $5^{\circ} \mathrm{C}$ : whereas laboratory experiments at less than $15^{\circ} \mathrm{C}$ and $25^{\circ} \mathrm{C}$ did not show different degradation rates, an experiment at $5^{\circ} \mathrm{C}$ yielded the relevant microcystin breakthrough, though eventually degradation rates reached those obtained under higher temperatures (Chorus \& Bartel, 2006). Hence, temperature monitoring in the well and in the surface water is useful in order to obtain an understanding of the prevailing temperature in the sediment flow path.

In summary, optimal conditions for biodegradation of microcystins are aerobic, with moderate to high temperatures $\left(>10-15^{\circ} \mathrm{C}\right)$ and an established microbial consortium (particularly in the clogging layer) capable of microcystin degradation. For degradation in the water phase, refer to Chapter 2.1.

\subsubsection{Degradation of cylindrospermopsin during bank filtration}

Removal of cylindrospermopsin (CYN) through subsurface passage or slow sand filtration schemes differs from that of microcystins in several ways:

1. A much higher fraction of CYN frequently occurs dissolved in water.

2. Dissolved CYN may persist in the waterbody for many weeks (Wörmer et al., 2008) after the producer bloom has subsided, particularly at low temperatures.

3. In temperate climates, CYN may occur about as frequently as microcystins, but concentrations rarely reach similarly high levels (maxima published from field samples are below $20 \mu \mathrm{g} / \mathrm{L}$ (Rücker et al., 1997; Bogialli et al., 2006; Rücker et al., 2007; Brient et al., 2009; see also section 2.2).

While points 1 and 2 increase the challenge for removal through sediment passage, point 3 may be a de-warning if high concentrations can be reliably excluded. 
Under some conditions, CYN elimination in the subsurface or slow sand filter tends to be less effective than for microcystins: experiments by Klitzke et al. (2011b) showed that sorption of CYN to various sediments was very poor, and there was virtually no CYN retention on purely sandy sediments (Klitzke et al., 2010). Also, the presence of clay did not enhance CYN sorption (Klitzke et al., 2011b). The role of sediment organic carbon is still unclear, because at present, results on the role of organic carbon in CYN sorption are inconsistent, showing very high sorption on organic mud (Klitzke et al., 2011b) but no sorption on a "schmutzdecke" (Klitzke et al., 2011a). This uncertainty emphasises the importance of conditions conducive to biodegradation to ensure an efficient CYN removal - for CYN, these conditions are more crucial than for microcystins.

Redox conditions have been shown to be particularly crucial for CYN elimination: under anaerobic conditions, lag phases can last weeks, and even after the lag phase, degradation may remain incomplete even if residence times amount to many weeks (Klitzke \& Fastner, 2012).

Preconditioning of sediments and flow rate also have a major impact: lag phases may last up to 3 weeks until a sufficiently large microbial community has developed and CYN breakdown commences (Klitzke et al., 2010). This implies that sediments need to have previous contact to CYN for at least 3 weeks before CYN is removed effectively. In practice, where CYN concentrations in the feed water build up over time, this may not prove to be a problem. However, additionally, contact times are sufficient for effective biodegradation only if the flow rate is sufficiently low (i.e., approximately $0.2 \mathrm{~m} / \mathrm{d}$ ); at higher flow rates (i.e., $0.7 \mathrm{~m} / \mathrm{d}$ and $1.2 \mathrm{~m} / \mathrm{d}$ ), the shorter residence times in the sediment will not allow for CYN degradation, and hence, CYN breakthrough is likely (Klitzke et al., 2011a).

Low temperature (i.e., $10^{\circ} \mathrm{C}$ or less) retarded CYN degradation by a factor of 10 in comparison with $20^{\circ} \mathrm{C}$ (Klitzke \& Fastner, 2012).

\subsubsection{Degradation of other cyanotoxins during bank filtration}

For the elimination of the other cyanotoxins by sediment passage, few experimental results have been published. For Anatoxin-a (ATX), rapid degradation already in the waterbody is well known (Rapala et al., 1994; see also section 2.3), and the half-life of ATX elimination in natural surface water studied in a batch system amounted to 4 weeks (Klitzke et al., 2011a).

In the sediment, ATX is eliminated through both sorption and degradation (Klitzke et al., 2011a): while on sandy sediments, ATX adsorbed very weakly, sorption was enhanced in sediments containing clay or organic carbon (Klitzke et al., 2011b). Column experiments with a filter velocity of approximately $1.4 \mathrm{~m} / \mathrm{d}$ showed ATX retardation on sandy sediments due to sorption. However, sorption was reversible and only attenuated peak concentrations of ATX, but not the overall ATX breakthrough. Degradation took place only 
in the presence of DOC and hence resulted in ATX elimination of approximately $35 \%$ of the initial concentration (Klitzke et al., unpublished data).

So far, published results of systematic studies on ATX degradation in sediments are only available from laboratory batch studies (Klitzke et al., 2011a). With an initial concentration of 10-15 $\mu \mathrm{g} / \mathrm{L}$ ATX (under oxic conditions and at room temperature of approximately $20^{\circ} \mathrm{C}$ ), it took 7 days for concentrations to drop below $1 \mu \mathrm{g} / \mathrm{L}$ following sediment contact. At $10^{\circ} \mathrm{C}$, elimination slowed down by approximately a factor of 2 . Under anoxic conditions, ATX elimination in sediments was decelerated also by about a factor of 2. Degradation in sediments under all conditions investigated took place without a lag phase; that is, it commenced without any delay, suggesting that preconditioning is not required.

Burns et al. (2009) report an efficient sorption of saxitoxins (STX) on a sandy-silty sediment, parts of which had very high amounts of clay and silt (up to $89.6 \%$ silt) for an initial concentration of $5 \mu \mathrm{g} / \mathrm{L}$. Besides, SXT sorbed on clay minerals with sorption increasing with increasing cation-exchange capacity. Romero et al. (2014) reported much lower sorption for SXT and neo-SXT (between $40 \%$ and $80 \%$ ) on a sediment retrieved from a bank filtration site with only $4 \%$ fines $(<0.063 \mathrm{~mm})$. Saxitoxin removal in sand filters of both a water treatment plant and a wastewater treatment plant proved very inefficient (Kayal et al., 2008; Ho et al., 2012). In the wastewater treatment plant filter, SXT toxicity was even increased after filter passage (Ho et al., 2012). These findings suggest SXTs to be very persistent. The studies mentioned were conducted at filter velocities of 7.2 and $14.4 \mathrm{~m} / \mathrm{d}$, respectively.

As degradation processes are strongly influenced by residence times (Klitzke et al., 2011a), it remains unclear whether SXT breakdown would increase at lower flow rates (i.e., $<1 \mathrm{~m} / \mathrm{d}$ ) as they may be encountered in riverbank filtration scenarios.

\subsubsection{Planning, design and construction of sediment passage for cyanotoxin control}

The general features of a managed aquifer recharge (MAR) site are determined by (i) subsurface characteristics, (ii) the design and operation of the drinking-water production wells (including distance from the bank/ infiltration pond, filter depth and pumping rate) and (iii) hydrochemical and biological conditions. Similarly, performance of slow sand filters depends on the choice of sediment, size and depth of the filter as well as on the flow rate.

For bank filtration, the subsurface characteristics are given by the lithological parameters of the aquifer, and the only way to influence them is to choose the most suitable well locations along the banks of a river or lake. While coarse material (coarse sand and gravel) is often preferred for well construction in order to achieve highest productivity, finer material like 
middle- to fine-grained sand is more effective for the removal of particles and substances, with the challenge of combining a high straining effect with sufficient hydraulic conductivity. The same is true for other MAR techniques and slow sand filters, though cell removal may be achieved by filtration of the inlet water prior to infiltration so that grain size distribution will not be as important as during bank filtration. The basis for planning therefore will include a detailed hydrogeological site investigation prior to well construction.

Besides well position, screen depth also needs to be planned carefully, as the point of abstraction is crucial for residence times and these characteristics again are crucial for toxin removal rates - as well as for the fraction of groundwater relative to filtered surface water (leading to cyanotoxin dilution; see Figure 9.3). Basic information for the positioning of the wells and determining filter depth is derived from hydrogeological site investigations, including the total depth of the aquifer, the position of confining layers and a first assessment of the hydraulic conductivities (usually from grain size analysis). Hydraulic computer models (simple models obtainable as shareware, e.g., the "Bank Filtration Simulator"; Rustler et al., 2009) can then be used to simulate different well settings in order to find an optimum concerning productivity, residence time and share of ambient groundwater.

\subsubsection{Critical aspects of operation, maintenance and monitoring}

The residence time of surface water in the subsurface is crucial for an effective cyanotoxin degradation, and residence time depends on the flow rate in the subsurface as well as on the distance between the surface waterbody and the well. Well operation can vary with respect to the pumping rates and regimes that is, continuously at a constant level or in an interval mode. It is therefore important to determine residence times for the range of potential operating conditions. Simple hydraulic models may provide a first assessment (Rustler et al., 2009). Tracer measurements, however, will reduce the uncertainty of this approach. Suitable tracers are characterised by their ability to be transported in the aquifer without sorption, degradation or any other reaction that may change the total load of this substance in the aqueous phase. A simple way of determining residence times is to monitor substances or parameters in the surface waterbody that show temporal variations (e.g., temperature), and to measure the offset of these variations over time in observation wells close to the waterbody (taking into account possible retardation coefficients).

If cyanotoxins break through the subsurface, their concentrations in the well water will depend on the proportion of bank filtrate relative to that of groundwater. Mixing ratios between surface water and groundwater can be assessed from the concentration of substances that show distinctive 
differences in concentration between groundwater and surface water (e.g., salinity or organic trace substances).

Flow rates as well as removal efficacy for many substances are affected by the gradual build-up of a clogging layer ("schmutzdecke"). Increasing build-up of a clogging layer will lead to reduced flow rates and eventually to the formation of anoxic zones. For this reason, the clogging layer is removed from slow sand filters at intervals which depend upon the infiltration rate loss. Some managed aquifer recharge (MAR) sites are also subject to regular cleaning of the uppermost layer, that is, removing the clogging layer. In bank filtration settings, the degree of clogging may vary in time, due to variations in sedimentation and biological activity, but the existence of a clogging layer is likely in nearly all cases. A complete lack of a clogging layer is conceivable in rivers with high flow rates and erosion as predominant process, but in such situations cyanobacterial blooms are unlikely. Changes in clogging can be monitored by measuring the head loss (i.e., the difference in water level) between the surface water supply and the groundwater.

For many substances, clogging layers contribute significantly to both sorption and degradation processes: they provide fine particles with a high capacity for contaminant sorption and harbour a high share of the degrading microorganisms. This was also assumed for cyanotoxins; however, relevance of this mechanism was neither confirmed for the removal of microcystins nor for that of cylindrospermopsin: experimental results showed no effect of the presence or absence of a clogging layer on a slow sand filter on their removal (Grützmacher et al., 2007; Klitzke et al., 2011a) - possibly because the sorption of these toxins is poor or null and thus the time spent in the clogging layer was too short for biodegradation to be effective. Data on the role of the clogging layer for the removal of other cyanotoxins are lacking, but due to its higher sorption potential, a clogging layer may be relevant, for example, for the degradation of Anatoxin-a. Also, for coarse-grained material, the clogging layer may have an impact not through sorption, but by improving filter action as strainer to remove cells and thus cell-bound toxins.

A more crucial parameter for slow sand filters is the exchange of the entire sediment body, as biodegradation takes place throughout the filter body and is most effective if the filter is preconditioned, that is, colonised by microorganisms capable of degrading cyanotoxins.

Even if clogging layer removal is less relevant for the removal of the most frequently occurring cyanotoxins than generally assumed, documentation of removal is important to enable the assessment of filter flow rates. For slow sand filters, documentation is important for sediment exchange. Furthermore, timing of sediment exchange is preferably well before cyanobacterial blooms are expected in order to allow time for preconditioning of the filter. 


\subsubsection{Assessing the risk of cyanotoxin breakthrough where drinking-water is abstracted by magaged aquifer recharge and/or slow sand filtration}

The following checklist outlines information needed to assess cyanotoxin removal through subsurface passage. It is neither complete nor designed as a template for direct use, but rather needs to be specifically adapted to local conditions. Support from hydrogeological expertise is highly valuable for this assessment.

\section{CHECKLIST 9.2: COLLECTING INFORMATION ON THE RISK OF CYANOTOXIN BREAKTHROUGH WHERE DRINKING WATER IS ABSTRACTED BY MANAGED AQUIFER RECHARGE (MAR) ANDIOR SLOW SAND FILTRATION}

What are the hydrogeological characteristics in the area envisaged/used for infiltration?

- Determine the likely flow path from the surface waterbody to the well(s), including the screen depth of the production well(s).

- Determine the clay/silt content and fraction of organic matter of the soil or sediment through which water is likely to flow.

- Determine homogeneity of the soil or sediment.

- Determine likely redox and temperature conditions during subsurface passage.

- Estimate travel times of water between surface waterbody and drinking-water well (e.g., by using a conservative tracer or groundwater flow models).

- Estimate the share of ambient groundwater in the drinking-water well in relation to the share of bank filtrate (e.g., by using a conservative tracer or groundwater flow models).

- Assess whether previous contact of the sediments to cyanotoxins is likely.

How are managed aquifer recharge (MAR)/slow sand filtration operated?

- Are wells operated continuously or at intervals?

- How strongly does the clogging layer fluctuate (is it periodically removed)?

- For pond/trench/well infiltration/slow sand filtration: does an additional filtration step remove cells/particles prior to infiltration? 
Which hazardous events are likely to affect raw water offtake?

- How heavy are cyanobacterial blooms? How long do they persist, and what seasonal patterns do they show? Which toxins do they contain? (See Chapter 2 and section 4.6.I)

- Are wellheads likely to be flooded?

- Are erosive events possible that could affect the clogging layer or filterbed structure (e.g., during snowmelt, repeated freezing and thawing cycles)?

What regulatory framework exists for abstracting drinking-water?

- Are there groundwater abstraction regulations that need to be considered when planning bank filtration and/or artificial recharge?

Documentation and visualisation of information on the abstraction scheme and regime:

- Compile a summarising report and consolidate information from your checklist.

- Map spatial distribution of existing or potential sites for wells abstracting bank filtrate, if available together with maps of hydrogeological conditions.

Outcome of system assessment:

- Estimate the risk of cyanotoxin breakthrough in underground filtration: What maximum levels do you expect to find, and for which time periods?

- Estimate the uncertainty of this assessment: Is the information base sufficient to make management decisions? If not, which information gaps should be closed with which priority?

\subsubsection{Operational monitoring of sediment passage as control measure against cyanotoxins}

As discussed in Chapter 6, the most effective way to ensure that control measures are operating as intended is to monitor easily observable indicators that show whether structures are intact and processes operating as they should - that is, operational monitoring. For controlling cyanotoxin concentrations by sediment passage, operational monitoring of managed aquifer recharge (MAR) and slow filters can use parameters indicating flow and redox conditions in order to ensure sufficient residence times 
in the subsurface. Surveillance will check the records of this monitoring as well as the adequacy of planning and design. Table 9.2 summarises selected examples of the measures proposed above to control cyanotoxin concentrations in raw water intake and suggests approaches to their monitoring and surveillance to check whether controls are operating as intended.

Table 9.2 Examples for control measures in sediment passage with options for monitoring their functioning

\begin{tabular}{|c|c|c|}
\hline Process step & $\begin{array}{l}\text { Examples of control measures } \\
\quad \text { for sediment passage }\end{array}$ & $\begin{array}{l}\text { Options for monitoring } \\
\text { their functioning }\end{array}$ \\
\hline \multirow[t]{3}{*}{ Planning } & $\begin{array}{l}\text { Choose site with optimum } \\
\text { hydrogeological and technical } \\
\text { prerequisites (fine- to } \\
\text { medium-grained sand, land } \\
\text { availability for pond/well } \\
\text { construction) } \\
\text { For bank filtration: optimise } \\
\text { choice of locations and depths } \\
\text { for production wells to ensure } \\
\text { sufficient residence times in } \\
\text { the subsurface }\end{array}$ & $\begin{array}{l}\text { Review plans and applications for } \\
\text { permits in relation to } \\
\text { hydrogeological information; } \\
\text { inspect sites }\end{array}$ \\
\hline & $\begin{array}{l}\text { For other MAR techniques: assess } \\
\text { soil characteristics, potential } \\
\text { for rapid clogging during } \\
\text { blooms and site of recharge } \\
\text { in relation to production wells } \\
\text { to ensure sufficient residence } \\
\text { time in the subsurface }\end{array}$ & \\
\hline & $\begin{array}{l}\text { For slow filtration, to ensure } \\
\text { sufficient residence time } \\
\text { in the filter, consider } \\
\text { area and depth needed in } \\
\text { relation to water volume } \\
\text { and filtration time }\end{array}$ & $\begin{array}{l}\text { Review plans and applications } \\
\text { for permits }\end{array}$ \\
\hline \multirow[t]{2}{*}{$\begin{array}{l}\text { Design, } \\
\text { construction, } \\
\text { maintenance }\end{array}$} & $\begin{array}{l}\text { Ensure that wells are } \\
\text { constructed according to } \\
\text { best practice, avoiding short } \\
\text { circuits }\end{array}$ & $\begin{array}{l}\text { Assign experts, carry out maximum- } \\
\text { capacity pumping test, TV } \\
\text { inspection and borehole } \\
\text { geophysical examination; inspect } \\
\text { sites and records of maintenance }\end{array}$ \\
\hline & $\begin{array}{l}\text { Ascertain that minimum } \\
\text { residence times are achieved }\end{array}$ & $\begin{array}{l}\text { Use tracer investigations for } \\
\text { validation, daily temperature } \\
\text { measurements in surface water } \\
\text { and bank filtrate (observation } \\
\text { wells), water-level monitoring in } \\
\text { surface and groundwater }\end{array}$ \\
\hline
\end{tabular}

(Continued) 
Table 9.2 (Continued) Examples for control measures in sediment passage with options for monitoring their functioning

\begin{tabular}{|c|c|c|}
\hline Process step & $\begin{array}{l}\text { Examples of control measures } \\
\text { for sediment passage }\end{array}$ & Options for monitoring their functioning \\
\hline & $\begin{array}{l}\text { Modify well locations/filter } \\
\text { depth, if material proves } \\
\text { coarser than expected }\end{array}$ & $\begin{array}{l}\text { Grain size analysis of aquifer } \\
\text { material prior to well lining to } \\
\text { validate assumptions }\end{array}$ \\
\hline & $\begin{array}{l}\text { Remove clogging layer from } \\
\text { infiltration pond/basin or river } \\
\text { bank by dredging, in case } \\
\text { infiltration rates decrease and } \\
\text { anoxic conditions are } \\
\text { established }\end{array}$ & $\begin{array}{l}\text { Water-level monitoring in surface } \\
\text { and groundwater, redox } \\
\text { measurements in bank filtrate } \\
\text { observation well }\end{array}$ \\
\hline \multirow[t]{4}{*}{ Operation } & $\begin{array}{l}\text { For artificial recharge and slow } \\
\text { sand filters: avoid clogging by a } \\
\text { regular removal of clogging } \\
\text { layer (preferably before } \\
\text { blooms are expected) }\end{array}$ & Monitor well production rates \\
\hline & $\begin{array}{l}\text { Avoid anoxic or anaerobic } \\
\text { conditions by timely removal } \\
\text { of clogging layer }\end{array}$ & $\begin{array}{l}\text { Monitor oxygen content in bank } \\
\text { filtrate, possibly also DOC in } \\
\text { surface water, as indicators of } \\
\text { oxygen consumption }\end{array}$ \\
\hline & $\begin{array}{l}\text { After sediment exchange, } \\
\text { consider extending residence } \\
\text { times by reducing pumping } \\
\text { rates/hydraulic head }\end{array}$ & $\begin{array}{l}\text { Inspect documentation of pumping } \\
\text { rates/groundwater tables and } \\
\text { records of sediment exchange }\end{array}$ \\
\hline & $\begin{array}{l}\text { For bank filtration, operational } \\
\text { control options are limited to the } \\
\text { pumping regime: If possible, } \\
\text { during cyanobacterial blooms } \\
\text { switch to production wells } \\
\text { with a higher share of } \\
\text { groundwater and reduce } \\
\text { pumping rates at critical wells }\end{array}$ & $\begin{array}{l}\text { Inspect records of well operation } \\
\text { and pumping rates; measure tracer } \\
\text { for the proportion of bank filtrate } \\
\text { in production well regularly }\end{array}$ \\
\hline
\end{tabular}

In addition to the operational monitoring of the functioning of control measures, occasional cyanotoxin monitoring in the offtake is important to verify comprehensively that initial cyanotoxin concentrations do not exceed the concentration for which the system is designed.

\subsubsection{Validation of control measures in sediment passage}

Whether or not sediment passage is sufficiently effective in eliminating cyanotoxins can best be validated by following bloom events with samples from a drinking-water production well and analysing them for the cyanotoxins which occur in the waterbody. For this purpose, indicators such as cell counts or pigment analysis are not applicable, as their 
elimination rates will differ from those of the dissolved cyanotoxins. If observation wells are available or can be installed between the drinking-water production well and the waterbody, they provide an excellent opportunity to follow the concentration decline. Timing of sampling in relation to the travel time of the water in the subsurface is important in order not to miss the concentration peak as it moves through the subsurface. It is also useful to include tracer measurements to characterise travel times in the subsurface.

The handicap of validation by following bloom events is that this is difficult to plan for waterbodies in which blooms do not occur regularly, or if capacities for sampling and analysis are not available. In such cases, a first approach to validation is to characterise the sediment as well as residence times in the subsurface, redox conditions and temperature as discussed above in order to estimate the likelihood of effective cyanotoxin elimination. Thus, conditions likely to be safe may be identified and investigations can focus on the more critical situations.

\section{REFERENCES}

Bertone E, Burford MA, Hamilton DP (2018). Fluorescence probes for real-time remote cyanobacteria monitoring: a review of challenges and opportunities. Water Res. 141:152-162.

Bogialli S, Bruno M, Curini R, Di Corcia A, Fanali C, Lagana A (2006). Monitoring algal toxins in lake water by liquid chromatography tandem mass spectrometry. Environ Sci Technol. 40:2917-2923.

Brient L, Lengronne M, Bormans M, Fastner J (2009). First occurrence of cylindrospermopsin in freshwater in France. Environ Toxicol. 24:415-420.

Burns JM, Hall S, Ferry JL (2009). The adsorption of saxitoxin to clays and sediments in fresh and saline waters. Water Res. 43:1899-1904.

Chorus I, Bartel H (2006). Retention and elimination of cyanobacterial toxins (microcystins) through artificial recharge and bank filtration. Berlin: KWB:143 pp.

Corbel S, Bouaïcha N, Mougin C (2014). Dynamics of the toxic cyanobacterial microcystin-leucine-arginine peptide in agricultural soil. Environ Chem Lett. 12:535-541.

Dillon P (2005). Future management of aquifer recharge. Hydrogeol J. 13:313-316.

Ellis KV, Wood WE (1985). Slow sand filtration. CRC Critical Reviews in Environ Science and Technology. 15:315-354.

Fastner J, Chorus I, Willmitzer H, Rabe C (2001). Reducing intake of microcystins at the Deesbach Reservoir drinking-water abstraction system. In: Chorus I, editors: Cyanotoxins: occurrence, causes, consequences. Berlin: Springer:229-231.

Grützmacher G, Bartel H, Chorus I (2007). Cyanobakterientoxine bei der Uferfiltration. Berlin: Umweltbundesamt:345-353.

Grützmacher G, Böttcher G, Chorus I, Bartel H (2002). Removal of microcystins by slow sand filtration. Environ Toxicol. 17:386-394.

Grützmacher G, Wessel G, Klitzke S, Chorus I (2010). Microcystin elimination during sediment contact. Environ Sci Technol. 44:657-662. 
Haig S, Collins G, Davies R, Dorea C, Quince C (2011). Biological aspects of slow sand filtration: past, present and future. Water Sci Technol Water Supply. 11:468-472.

Ho L, Tang T, Monis PT, Hoefel D (2012). Biodegradation of multiple cyanobacterial metabolites in drinking water supplies. Chemosphere. 87:1149-1154.

Kayal N, Newcombe G, Ho L (2008). Investigating the fate of saxitoxins in biologically active water treatment plant filters. Environ Toxicol. 23:751-755.

Klitzke S, Apelt S, Weiler C, Fastner J, Chorus I (2010). Retention and degradation of the cyanobacterial toxin cylindrospermopsin in sediments - The role of sediment preconditioning and DOM composition. Toxicon. 55:999-1007.

Klitzke S, Apelt S, Weiler C, Fastner J, Chorus I (2011a). The fate of cylindrospermopsin and anatoxin-a during sediment passage. In: Wiedner C, editor: Development of Toxic Nostocales (Cyanobacteria) in the Course of Declining Trophic State and Global Warming NOSTOTOX - Final project report. Berlin: KompetenzZentrum Wasser: 87-99.

Klitzke S, Beusch C, Fastner J (2011b). Sorption of the cyanobacterial toxins cylindrospermopsin and anatoxin-a to sediments. Water Res 45:1338-1346.

Klitzke S, Fastner J (2012). Cylindrospermopsin degradation in sediments-The role of temperature, redox conditions, and dissolved organic carbon. Water Res. 46:1549-1555.

Machado J, Campos A, Vasconcelos V, Freitas M (2017). Effects of microcystin-LR and cylindrospermopsin on plant-soil systems: a review of their relevance for agricultural plant quality and public health. Environ Res. 153:191-204.

Maeng SK, Ameda E, Sharma SK, Gruetzmacher G, Amy GL (2010). Organic micropollutant removal from wastewater effluent-impacted drinking water sources during bank filtration and artificial recharge. Water Res. 44:4003-4014.

Miller MJ, Critchley MM, Hutson J, Fallowfield HJ (2001). The adsorption of cyanobacterial hepatotoxins from water onto soil during batch experiments. Water Res. 35:1461-1468.

Miller MJ, Hutson J, Fallowfield HJ (2005). The adsorption of cyanobacterial hepatoxins as a function of soil properties. J Water Health. 3:339-347.

Pereira SP, de Cerqueira Martins F, Gomes LNL, do Vale Sales M, De Pádua VL (2012). Removal of cyanobacteria by slow sand filtration for drinking water. J Water, Sanit Hyg Dev. 2:133-145.

Rapala J, Lahti K, Sivonen K, Niemelä SI (1994). Biodegradability and adsorption on lake sediments of cyanobacterial hepatotoxins and anatoxin-a. Lett Appl Microbiol. 19:423-428.

Romero L, Mondardo R, Sens M, Grischek T (2014). Removal of cyanobacteria and cyanotoxins during lake bank filtration at Lagoa do Peri, Brazil. Clean Technol Environ Policy. 16:1133-1143.

Rücker J, Stüken A, Nixdorf B, Fastner J, Chorus I, Wiedner C (2007). Concentrations of particulate and dissolved cylindrospermopsin in 21 Aphanizomenondominated temperate lakes. Toxicon. 50:800-809.

Rücker J, Wiedner C, Zippel P (1997). Factors controlling the dominance of Planktothrix agardhii and Limnothrix redekei in eutrophic shallow lakes. Hydrobiologia. 342/343:107-15. 
Rustler M, Boisserie-Lacroix C, Holzbecher E, Grützmacher G (2009). Combination of MAR and adjusted conventional treatment processes for an Integrated Water Resources Management. Deliverable 5.2.5, Bank Filtration Simulator. European Commission, Bruxelles. 50 pp. www.kompetenz-wasser.de/wpcontent/uploads/2017/05/d5-2-5.pdf.

Sprenger C, Hartog N, Hernández M, Vilanova E, Grützmacher G, Scheibler $\mathrm{F}$ et al. (2017). Inventory of managed aquifer recharge sites in Europe: historical development, current situation and perspectives. Hydrogeol J. 25:1909-1922.

Tufenkji N, Ryan JN, Elimelech M (2002). The promise of bank filtration. Environ Sci Technol. 36:422A-428A.

Wörmer L, Cirés S, Carrasco D, Quesada A (2008). Cylindrospermopsin is not degraded by co-occurring natural bacterial communities during a 40-day study. Harmful Algae. 7:206-213.

Wu X, Xiao B, Li R, Wang C, Huang J, Wang Z (2011). Mechanisms and factors affecting sorption of microcystins onto natural sediments. Environ Sci Technol. 45:2641-2647.

Zamyadi A, Choo F, Newcombe G, Stuetz R, Henderson RK (2016). A review of monitoring technologies for real-time management of cyanobacteria: recent advances and future direction. Trends Anal Chem. 85:83-96. 